PRACE GEOGRAFICZNE

zeszyt $148,2017,11-32$

doi: 10.4467/20833113PG.17.001.6269

Instytut Geografii i Gospodarki Przestrzennej UJ

Wydawnictwo Uniwersytetu Jagiellońskiego

\title{
EKSTREMALNE WARTOŚCI WSKAŹNIKÓW CHWIEJNOŚCI ATMOSFERY W POLSCE I ICH ZWIĄZEK Z MECHANIZMAMI OGRANICZAJĄGYMI ROZWÓJ KONWEKCJI
}

\author{
Daniel Celinski-Mystaw, Angelika Palar:
}

\section{Extreme values of atmospheric instability indices in Poland and their relationship with factors inhibiting the development of convection}

Abstract: The primary goal of the study was to examine the temporal and spatial variability of values of selected atmospheric instability indices over Poland for the period 2005-2014. The research involved six indices most frequently applied in convection forecasting Convective Available Potential Energy, K-Index, Lifted Index, Severe Weather Threat Index, Showalter Index and Total Totals Index. The data from three Polish upper air sounding stations (Łeba, Legionowo, Wrocław), as well as SYNOP codes on present and past weather and reports on severe meteorological phenomena from the European Severe Weather Database were used in this study. It was found that extremely high values of the selected indices were characterised by strong temporal and spatial variability. Moreover, a detailed analysis of the days when no convective events were observed, despite extreme values of instability indices, demonstrated that the occurrence of isothermal or inversion layers were the most common mechanisms inhibiting the development of severe convective phenomena. Convection was also inhibited when the area was free from an influence of atmospheric fronts, convergence zones or low-pressure troughs.

Keywords: instability indices, severe convective phenomena, convection inhibition, Poland, upper air soundings 
Zarys treści: Głównym celem opracowania jest ocena czasowej i przestrzennej zmienności ekstremalnych wartości wybranych wskaźników chwiejności w Polsce w latach 2005-2014. Badania wykonano w odniesieniu do ekstremalnych wartości sześciu indeksów chwiejności - Convective Available Potential Energy, K-Index, Lifted Index, Severe Weather Threat Index, Showalter Index i Total Totals Index. Podstawę badań stanowiły dane pomiarowe z polskich stacji aerologicznych - Łeba, Legionowo, Wrocław - z lat 2005-2014. Ponadto w opracowaniu wykorzystano informacje z depesz SYNOP i raporty o groźnych zjawiskach meteorologicznych bazy European Severe Weather Database. Badania pozwoliły na rozpoznanie wyraźnej czasowej i przestrzennej zmienności ekstremalnych wartości omawianych wskaźników. Szczegółowej analizie poddano trzy dni, w których mimo ekstremalnych wartości wybranych indeksów nie wystąpiły żadne z analizowanych zjawisk konwekcyjnych. Wykazano, że hamowaniu ruchów pionowych zwykle sprzyjało występowanie warstw izotermicznych i inwersyjnych w swobodnej atmosferze. Dodatkowym czynnikiem ograniczającym rozwój konwekcji było położenie badanego obszaru poza zasięgiem oddziaływania frontów atmosferycznych, stref zbieżności lub zatok niżowych.

Stowa kluczowe: wskaźniki chwiejności, zjawiska konwekcyjne, hamowanie konwekcji, Polska, sondaże aerologiczne

\section{Wprowadzenie}

Występowanie silnych zjawisk konwekcyjnych, w szczególności burz, gradu, trąb powietrznych i gwałtownych porywów wiatru, stanowi jedno z najpoważniejszych zagrożeń naturalnych wpływających na funkcjonowanie ekosystemów i działalność człowieka (Čabajová 2011; Doswell III i in. 2012). Mimo prowadzonych od wielu lat badań zjawiska te są nadal trudne do precyzyjnego przewidywania, zwłaszcza w skali lokalnej (Rauhala, Schultz 2009). Możliwość poprawy jakości prognoz pogody, w tym głównie prognoz nowcastingowych, stwarza zastosowanie wskaźników chwiejności atmosfery. Opracowane w połowie XX w. indeksy stanowią nie tylko istotną zmienną synoptyczną, ale także zmienną klimatologiczną pozwalającą na określenie czasowego i przestrzennego zróżnicowania warunków potencjalnie sprzyjających rozwojowi głębokiej konwekcji (DeRubertis 2006).

Badania czasowej i przestrzennej zmienności wartości wskaźników chwiejności atmosfery były prowadzone zarówno na podstawie danych aerologicznych (DeRubertis 2006; Venkat Ratnam i in. 2013), jak i reanaliz klimatologicznych (Brooks i in. 2007; Riemann-Campe i in. 2009). Opracowania te dotyczyły przede wszystkim wskaźników najczęściej stosowanych w praktyce synoptycznej, tj. Convective Available Potential Energy - CAPE i Convective Inhibition - CIN (Blanchard 1998; Romero i in. 2007; Brooks 2009; Riemann-Campe i in. 2009). Zdecydowanie rzadziej analizie poddawano wartości wskaźników Lifted Index - LI, Severe Weather Threat Index - SWEAT, Showalter Index - SI, K-index - KI i Total Totals Index - TTI 
(Siedlecki 2009; Venkat Ratnam i in. 2013). Przykładowo obszar europejski cechuje się wyraźnym cyklem rocznym oraz silnym przestrzennym zróżnicowaniem wartości wskaźników chwiejności (Romero i in. 2007; Siedlecki, Rzepa 2008; Siedlecki 2009). Zwiększony dopływ energii słonecznej i nagrzewanie powierzchni czynnej prowadzi do wzrostu wartości CAPE i spadku wartości CIN w sezonie letnim. Roczne amplitudy ich wartości rosną wraz ze wzrostem odległości od Oceanu Atlantyckiego i stopniem kontynentalizmu (Siedlecki, Rzepa 2008). Obszarem charakteryzującym się najwyższymi wartościami wskaźnika CAPE jest rejon Morza Śródziemnego, najwyższe zaś wartości wskaźników KI, SWEAT i TTI obserwuje się w Alpach i Karpatach (Siedlecki 2009).

Badania związków występowania zjawisk konwekcyjnych z wartościami wskaźników chwiejności atmosfery były podejmowane m.in. w odniesieniu do burz (Sanchez i in. 2009; Gubenko, Rubinshtein 2015), gradu (Palencia i in. 2010; Hand, Cappelluti 2011) i trąb powietrznych (Brooks i in. 2003; Romero i in. 2007). Wyznaczono szereg silnie zróżnicowanych przestrzennie wartości progowych, których przekroczenie może prowadzić do wystąpienia niebezpiecznych zjawisk pogodowych. Jednocześnie zdecydowanie rzadsze są opracowania, w których omawia się problem hamowania konwekcji uwarunkowanego przede wszystkim występowaniem warstw izotermicznych lub inwersyjnych w środkowej i górnej troposferze (Chaboureau i in. 2004; Wong, Dessler 2005; Riemann-Campe i in. 2009).

Niniejsze opracowanie stanowi kontynuację badań zmienności wartości wskaźników chwiejności atmosfery oraz przyczyn hamowania rozwoju konwekcji w troposferze. Głównym celem opracowania była ocena czasowej i przestrzennej zmienności ekstremalnych wartości wybranych indeksów w Polsce w latach 2005-2014. Dodatkowo na podstawie wybranych przypadków określono mechanizmy ograniczające rozwój zjawisk konwekcyjnych w warunkach ekstremalnych wartości wskaźników chwiejności.

\section{Dane i metody badawcze}

Badania wykonano na podstawie danych aerologicznych pozyskanych z bazy Department of Atmospheric Science University of Wyoming (http://weather.uwyo. edu/, 15.02.2015). Obejmowały one wartości sześciu najczęściej stosowanych w prognozowaniu zjawisk konwekcyjnych wskaźników - CAPE, KI, LI, SWEAT, SWI i TTI, których szczegółowe opisy zestawiono w tab. 1. Do przeprowadzenia analiz wykorzystano dane pomiarowe $\mathrm{z}$ trzech polskich stacji aerologicznych (Legionowo, Łeba i Wrocław) z godziny 12.00 UTC. Badania obejmowały lata 2005-2014.

Zgodnie z definicją Międzyrządowego Zespołu ds. Zmian Klimatu - IPCC (http:// www.ipcc.ch, 15.05.2015) zjawisko ekstremalne definiowane jest jako rzadkie 
z punktu widzenia rozkładu statystycznego funkcji gęstości prawdopodobieństwa (10 lub 90 percentyl). W niniejszym opracowaniu omówione kryterium zostało dodatkowo zaostrzone, a za ekstremalne wartości wskaźników chwiejności atmosfery zostały uznane odpowiednio przypadki poniżej 5 percentyla dla wskaźników LI i SWI oraz powyżej 95 percentyla dla wskaźników CAPE, KI, SWEAT i TTI. Przyjęte wartości percentyli umożliwiają analizę około 18 przypadków rocznie. Należy zaznaczyć, że na niektórych obszarach jest to zbieżne ze średnią roczną liczbą dni

Tab. 1. Interpretacja wartości wybranych wskaźników chwiejności atmosfery

Table 1. Interpretation of values of the selected instability indices

\begin{tabular}{|c|c|}
\hline $\begin{array}{l}\text { Wskaźnik niestabilności atmosfery } \\
\text { Instability index }\end{array}$ & $\begin{array}{l}\text { Interpretacja wartości wskaźnika } \\
\text { Interpretation of index values }\end{array}$ \\
\hline $\begin{array}{l}\text { Energia potencjalna dostępna dla konwekcji } \\
\text { - CAPE (Moncrieff, Miller 1976) } \\
\qquad \text { CAPE }=\int_{L F C}^{E L} g\left(\frac{T_{V C z}-T_{V 0}}{T_{V E}}\right) d z\left[\frac{\mathrm{J}}{\mathrm{kg}}\right] \\
g-\text { przyspieszenie ziemskie } \\
\text { EL - wysokość poziomu równowagi } \\
\text { LFC - wysokość poziomu swobodnej konwekcji } \\
T_{\mathrm{Vcz}} \mathrm{T}_{\mathrm{vo}} \text { - temperatura wirtualna cząstki i otoczenia }\end{array}$ & 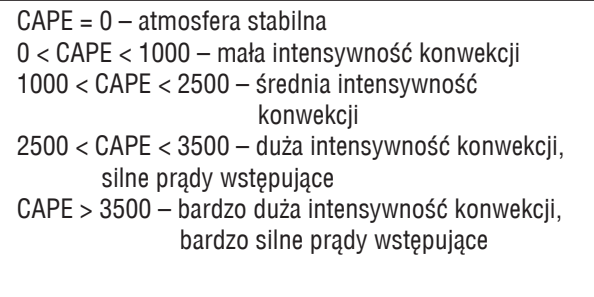 \\
\hline $\begin{array}{l}\text { K-Index (George 1960): } \\
\mathrm{K}=\left(\mathrm{T}_{850}-\mathrm{T}_{500}\right)+\mathrm{T}_{\mathrm{d} 850}-\left(\mathrm{T}_{700}-\mathrm{T}_{\mathrm{d} 700}\right)\left[{ }^{\circ} \mathrm{C}\right] \\
\mathrm{T}_{850}, \mathrm{~T}_{700}, \mathrm{~T}_{500}-\text { temperatura powietrza na poziomach } \\
\quad 850,700 \mathrm{i} 500 \mathrm{hPa}\left[{ }^{\circ} \mathrm{C}\right] \\
\mathrm{T}_{\mathrm{d} 850,}, \mathrm{~T}_{\mathrm{d} 700}-\text { temperatura punktu rosy na poziomach } \\
\quad 850 \mathrm{i} 700 \mathrm{hPa}\left[{ }^{\circ} \mathrm{C}\right]\end{array}$ & $\begin{array}{c}\mathrm{K}<20 \text { - prawdopodobieństwo wystąpienia burz }<20 \% \\
20<\mathrm{K}<25 \text { - prawdopodobieństwo wystąpienia burz: } \\
20 \%-40 \% \text {, pojedyncze komórki burzowe } \\
25<\mathrm{K}<30 \text { - prawdopodobieństwo wystapienia burz: } \\
41 \%-60 \% \text {, burze rozproszone } \\
30<\mathrm{K}<35-\text { prawdopodobieństwo wystapienia burz: } \\
61-80 \% \text {, rozbudowane układy burzowe } \\
\mathrm{K}>35 \text { - prawdopodobieństwo wystapienia burz: } \\
>80 \% \text {, liczne bardzo rozbudowane układy } \\
\text { burzowe }\end{array}$ \\
\hline $\begin{array}{l}\text { Lifted Index }-\mathrm{LI}(\text { Galway } 1956): \\
\mathrm{LI}=\mathrm{T}_{0500}-\mathrm{T}_{\text {cz500 }}\left[{ }^{\circ} \mathrm{C}\right] \\
\mathrm{T}_{\mathrm{O}_{050}}-\text { temperatura otoczenia na poziomie } 500 \mathrm{hPa} \\
{\left[{ }^{\circ} \mathrm{C}\right]} \\
\mathrm{T}_{\text {Czz500 }} \text { - temperatura cząstki unoszonej adiabatycznie } \\
\quad \text { z powierzchni Ziemi do poziomu } 500 \mathrm{hPa}\left[{ }^{\circ} \mathrm{C}\right]\end{array}$ & $\begin{array}{l}\mathrm{LI}>0 \text { - atmosfera stabilna } \\
0>\mathrm{LI}>-3-\text { mała niestabilność atmosfery, małe } \\
\text { prawdopodobieństwo wystąpienia słabych } \\
\text { burz } \\
-3>\mathrm{LI}>-5 \text { - średnia niestabilność, umiarkowane } \\
\text { prawdopodobieństwo wystapienia burz } \\
\mathrm{LI}<-5 \text { - atmosfera bardzo niestabilna, duże } \\
\text { prawdopodobieństwo wystąpienia silnych burz }\end{array}$ \\
\hline $\begin{array}{l}\text { Showalter Index }-\mathrm{SWI} \text { (Showalter 1953): } \\
\text { SWI }=\mathrm{T}_{0500}-\mathrm{T}_{\mathrm{CZ500}}\left[{ }^{\circ} \mathrm{C}\right] \\
\mathrm{T}_{0500}-\text { temperatura otoczenia na poziomie } 500 \mathrm{hPa} \\
{\left[{ }^{\circ} \mathrm{C}\right],} \\
\mathrm{T}_{\mathrm{cz500}}-\text { temperatura cząstki unoszonej z } 850 \text { do } 500 \\
\mathrm{hPa}\left[{ }^{\circ} \mathrm{C}\right]\end{array}$ & $\begin{array}{l}\text { SWI }>1-\text { burze mało prawdopodobne } \\
1>\mathrm{SWI}>-2-\text { prawdopodobne słabe burze } \\
-2>\mathrm{SWI}>-3-\text { prawdopodobne umiarkowane i silne } \\
\quad \text { burze } \\
-3>\text { SWI }>-6-\text { atmosfera bardzo niestabilna, warunki } \\
\quad \text { sprzyjające występowaniu gwałtownych burz } \\
\text { SWI }<-6 \text { - ekstremalna niestabilność, bardzo } \\
\text { gwałtowne burze }\end{array}$ \\
\hline
\end{tabular}




\begin{tabular}{|c|c|}
\hline $\begin{array}{l}\text { Wskaźnik niestabilności atmosfery } \\
\text { Instability index }\end{array}$ & $\begin{array}{l}\text { Interpretacja wartości wskaźnika } \\
\text { Interpretation of index values }\end{array}$ \\
\hline $\begin{array}{l}\text { Total Totals Index - } \mathrm{TTI} \text { (Miller 1972): } \\
\begin{array}{l}\mathrm{TTI}=\left(\mathrm{T}_{850}-\mathrm{T}_{500}\right)+\left(\mathrm{Td}_{850}-\mathrm{T}_{500}\right) \\
\mathrm{T}_{850}, \mathrm{~T}_{500}-\text { temperatura powietrza na poziomach } 850 \\
\quad \mathrm{i} 500 \mathrm{hPa}\left[{ }^{\circ} \mathrm{C}\right] \\
\mathrm{T}_{\mathrm{d850}}-\text { temperatura punktu rosy na poziomie } 850\left[{ }^{\circ} \mathrm{C}\right]\end{array}\end{array}$ & $\begin{array}{c}\mathrm{TTI}<40 \text { - atmosfera stabilna } \\
40>\mathrm{TTI}>44 \text { - rozwój konwekcji mało prawdopodobny } \\
44>\mathrm{TTI}>48 \text { - rozproszone umiarkowane i silne burze } \\
48>\mathrm{TTI}>50 \text { - lokalnie silne burze z małym gradem } \\
50>\mathrm{TTI}>55 \text { - rozproszone silne burze, możliwe } \\
\text { występowanie trąb powietrznych } \\
\text { i wodnych, a także gradu } \\
\text { TTI }>55 \text { - liczne silne burze, możliwe występowanie trąb } \\
\text { powietrznych i wodnych, a także gradu }\end{array}$ \\
\hline 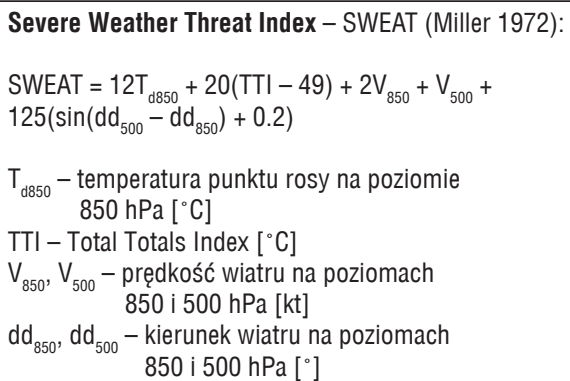 & 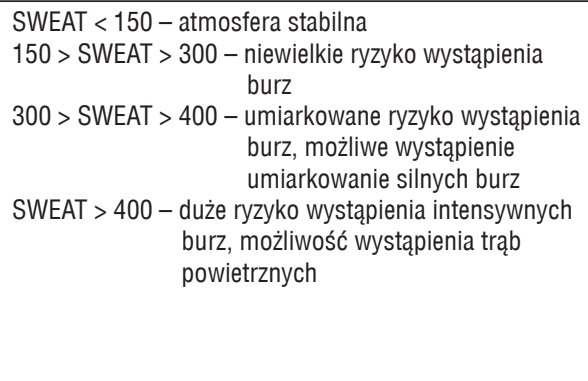 \\
\hline
\end{tabular}

z burzą. Konsekwencją tego mogło być również uwzględnienie przypadków, gdy wartości omawianych wskaźników sugerowały możliwość wystąpienia jedynie słabych zjawisk konwekcyjnych.

Do wyselekcjonowania liczby dni, w których mimo ekstremalnych wartości omawianych wskaźników nie wystąpiły silne zjawiska konwekcyjne (burze, silne opady atmosferyczne, silny wiatr), wykorzystano depesze SYNOP z godzin 6, 9, 12, 15 i 18 UTC (http://www.ogimet.com/, 15.04.2015). Zanalizowano wyłącznie dane pomiarowe ze stacji meteorologicznych zlokalizowanych w promieniu do $150 \mathrm{~km}$ od miejsca wykonania sondażu atmosfery - było to odpowiednio 14 stacji w pobliżu Łeby, 15 stacji w pobliżu Legionowa oraz 16 stacji w pobliżu Wrocławia (ryc. 1). Dla weryfikacji otrzymanych wyników wykorzystano raporty o groźnych zjawiskach meteorologicznych z bazy European Severe Weather Database (http://www.eswd. eu/, 15.04.2015), a w wybranych przypadkach również dane z sytemu lokalizacji wyładowań atmosferycznych (http://www.lightningmaps.org, 15.06.2015; http://www. pogodynka.pl, 15.06.2015; http://www.wetterzentrale.de, 15.06.2015).

Szczegółowej analizie poddano trzy z 26 wyselekcjonowanych dni, w których mimo ekstremalnych wartości omawianych wskaźników nie wystąpiły silne zjawiska konwekcyjne. Były to przypadki, w których założonym ekstremalnym wartościom energii potencjalnej dostępnej dla konwekcji (CAPE) towarzyszyły znaczące wartości energii hamującej (CIN). Dla każdej stacji aerologicznej wybrano po jednym przypadku z sezonu ciepłego. Dla określenia warunków synoptycznych kształtujących warunki 
pogodowe w tych dniach zostały wykorzystane archiwalne dolne mapy synoptyczne (http://www.knmi.nl/, 30.06.2015) oraz mapy topografii barycznej poziomów $850 \mathrm{hPa}$ i $500 \mathrm{hPa}$ (http://www.estofex.org, 30.06.2015; http://www.wetter3.de, 30.06.2015).

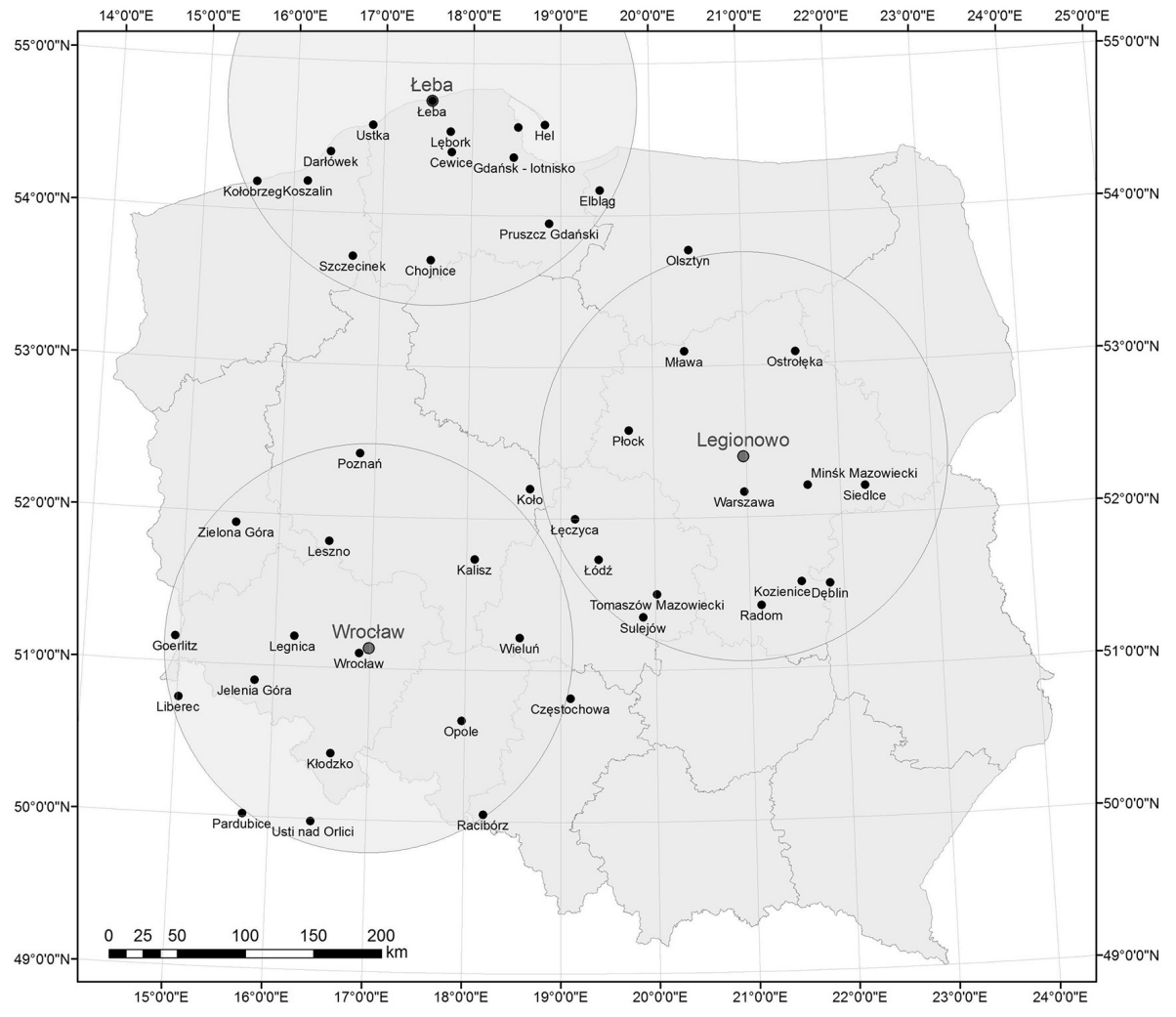

Ryc. 1. Lokalizacja stacji aerologicznych (Legionowo, Łeba, Wrocław) i stacji synoptycznych, których dane wykorzystano w analizach

Fig. 1. Location of upper air sounding stations (Legionowo, Łeba, Wrocław) and synoptic stations used in the study 


\section{Czasowa i przestrzenna zmienność ekstremalnych wartości wskaźników chwiejności atmosfery}

\section{Convective Available Potential Energy}

Ekstremalne wartości CAPE mieściły się odpowiednio w przedziale od 207 do $3025 \mathrm{~J} \cdot \mathrm{kg}^{-1}$ we Wrocławiu, od 90 do $1721 \mathrm{~J} \cdot \mathrm{kg}^{-1}$ w Legionowie i od $241 \mathrm{do} 2417 \mathrm{~J} \cdot \mathrm{kg}^{-1}$ w Łebie. Jak należało oczekiwać, najwięcej dni z najwyższymi wartościami występowało w okresie od maja do sierpnia z maksimum w lipcu - Wrocław (53) i Legionowo (58) oraz w sierpniu - Łeba (71) (ryc. 2). Wyraźne przesunięcie miesięcznego maksimum częstości występowania ekstremalnych wartości tego wskaźnika w Łebie było konsekwencją oddziaływania Morza Bałtyckiego - wolniejsze nagrzewanie powierzchni wodnej w stosunku do powierzchni lądowej. Wpływ akwenu morskiego zaznaczył się tam również w sezonie jesiennym i zimowym - wolniejsze ochładzanie akwenu i wynikający z tego częstszy napływ cieplejszego powietrza znad morza w kierunku lądu spowodował wyraźne wydłużenie okresu sprzyjającego występowaniu względnie wysokich wartości CAPE. Wartości tego wskaźnika charakteryzowały się także wyraźną zmiennością z roku na rok. Najwięcej omawianych dni wystąpiło w 2007 r. w Łebie (28), w 2012 r. w Legionowie (27), a w 2014 r. we Wrocławiu (32). Najmniej zaś w 2005 r. w Łebie (10), a w 2008 r. we Wrocławiu (3) i Legionowie (10).

Średnia z ekstremalnych wartości osiągała najwyższe wartości w czerwcu we Wrocławiu $\left(828 \mathrm{~J} \cdot \mathrm{kg}^{-1}\right)$ i Łebie $\left(462 \mathrm{~J} \cdot \mathrm{kg}^{-1}\right)$ oraz w lipcu w Legionowie $\left(813 \mathrm{~J} \cdot \mathrm{kg}^{-1}\right.$ ) (ryc. 3). Ze względu na znaczną asymetrię rozkładu wartości ekstremalnych zostały wyznaczone również wartości mediany - Wrocław (czerwiec - $606 \mathrm{~J} \cdot \mathrm{kg}^{-1}$ ), Łeba

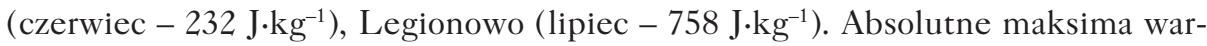
tości wskaźnika CAPE wyniosły odpowiednio $3025 \mathrm{~J} \cdot \mathrm{kg}^{-1}$ (20 czerwca $2013 \mathrm{r}$.) we Wrocławiu, $2417 \mathrm{~J} \cdot \mathrm{kg}^{-1}$ (15 sierpnia 2010 r.) w Legionowie i $1721 \mathrm{~J} \cdot \mathrm{kg}^{-1}$ (18 lipca 2009 r.) w Łebie.

\section{K-Index}

Ekstremalnie wysokie wartości wskaźnika K-Index wahały się od $29,6^{\circ} \mathrm{C}$ do $40,8^{\circ} \mathrm{C}$ we Wrocławiu, od $31,0^{\circ} \mathrm{C}$ do $38,4^{\circ} \mathrm{C}$ w Legionowie i od $29,2^{\circ} \mathrm{C}$ do $40,6^{\circ} \mathrm{C}$ w Łebie. Najwięcej dni z omawianymi wartościami pojawiało się w okresie od maja do września z maksimum w lipcu - Wrocław (57) i Legionowo (66) oraz w sierpniu - Łeba (56) (ryc. 2). Analogicznie do wskaźnika CAPE zaobserwowano wystąpienie wyraźnego przesunięcia miesięcznego maksimum częstości występowania ekstremalnych wartości wskaźnika K-Index w Łebie, co może być związane ze wspomnianym już wpływem Morza Bałtyckiego. Wpływ akwenu morskiego zaznaczył się tam również w sezonie jesiennym i zimowym. Także rozkład z roku na rok wskazywał na istotne 
różnice w liczbie dni charakterystycznych. W badanym okresie najwięcej omawianych przypadków wystąpiło w 2011 r. w Łebie (25), a w 2014 r. we Wrocławiu (30) i w Legionowie (26). Najmniej z kolei w 2005 r. w Legionowie (9), w 2008 r. w Łebie (12) oraz w 2013 r. we Wrocławiu (10).

Średnia z ekstremalnych wartości indeksu KI w sezonie letnim cechowała się wyrównanym przebiegiem. Najwyższe wartości osiągała ona w lipcu $\left(40,8^{\circ} \mathrm{C}\right.$ we Wrocławiu, $40,6^{\circ} \mathrm{C}$ w Łebie i $38,4^{\circ} \mathrm{C}$ w Legionowie) (ryc. 3). Najwyższe miesięczne wartości mediany występowały w lipcu i wyniosły $31,7^{\circ} \mathrm{C}$ we Wrocławiu, $31,6^{\circ} \mathrm{C}$ we Łebie oraz $32,8^{\circ} \mathrm{C}$ w Legionowie. Absolutne maksima wartości omawianego wskaźnika wyniosły $40,8^{\circ} \mathrm{C}$ (20 lipca 2007 r. ) we Wrocławiu, $38,4^{\circ} \mathrm{C}$ (6 lipca 2012 r.) w Legionowie i $40,6^{\circ} \mathrm{C}$ (6 lipca 2012 r.) w Łebie.

\section{Lifted Index}

Ekstremalnie niskie wartości wskaźnika Lifted Index, które utożsamiać należy $\mathrm{z}$ największą chwiejnością atmosfery, mieściły się w granicach od $-0,8^{\circ} \mathrm{C}$ do $-7,8^{\circ} \mathrm{C}$ we Wrocławiu, od $-1,0^{\circ} \mathrm{C}$ do $-7,3^{\circ} \mathrm{C}$ w Legionowie i od $0,2^{\circ} \mathrm{C}$ do $-6,5^{\circ} \mathrm{C}$ w Lebie. Dni z omawianymi wartościami pojawiały się najczęściej w sezonie letnim z maksimum w lipcu we Wrocławiu (53) i Legionowie (61) oraz sierpniu w Łebie (61) (ryc. 2). Podobnie do analizowanych wcześniej wskaźników wyraźne przesunięcie rocznego maksimum liczby dni z ekstremalnymi wartościami indeksu LI, a także uprzywilejowanie sezonu zimowego, zaznaczyło się w Łebie. Sporadycznie dni z ekstremalnymi wartościami LI pojawiały się tam również w styczniu, grudniu i listopadzie. Wiosną najwięcej omawianych dni wystąpiło w Legionowie i Wrocławiu, jesienią zaś w pozostającej pod wpływem akwenu morskiego Łebie. Wyraźne różnice w liczbie dni charakterystycznych wykazywał także rozkład z roku na rok. W badanym okresie najwięcej omawianych przypadków wystąpiło w 2007 r. w Legionowie (28), a 2014 r. w Łebie (28) i we Wrocławiu (30). Najmniej z kolei w 2005 r. w Legionowie (11), w 2008 r. we Wrocławiu (4) oraz w latach 2005 i 2009 w Łebie (13).

Średnia z ekstremalnych wartości wskaźnika LI osiągała w maju w Legionowie $-2,7^{\circ} \mathrm{C}$, a w czerwcu we Wrocławiu $-2,8^{\circ} \mathrm{C}$ (ryc. 3). W przypadku Łeby indeks LI przyjmował zbliżone wartości w okresie od maja do sierpnia i w październiku, oscylując w granicach od $-1,1^{\circ} \mathrm{C}$ do $-1,3^{\circ} \mathrm{C}$. Najniższe wartości mediany wystąpiły w maju $\left(-2,3^{\circ} \mathrm{C}\right)$ w Legionowie i w czerwcu $\left(-2,4^{\circ} \mathrm{C}\right)$ we Wrocławiu. Wartość omawianej miary pozycyjnej dla Łeby w miesiącach od maja do sierpnia i w październiku wynosiła natomiast około $-0,9^{\circ} \mathrm{C}$. Absolutne minima wartości indeksu LI sięgnęły $-7,8^{\circ} \mathrm{C}$ (20 czerwca 2013 r.) we Wrocławiu, $-7,3^{\circ} \mathrm{C}$ (1 lipca 2012 r.) w Legionowie i $-6,5^{\circ} \mathrm{C}$ (18 lipca 2009 r.) w Łebie. 


\section{Showalter Index}

Ekstremalne wartości (ekstremum dolne) wskaźnika Showalter Index, które podobnie do wskaźnika LI należy utożsamiać z warunkami najbardziej sprzyjającymi rozwojowi konwekcji, oscylowały w granicach od $1,1^{\circ} \mathrm{C}$ do $-4,9^{\circ} \mathrm{C}$ we Wrocławiu, od $0,5^{\circ} \mathrm{C}$ do $-4,8^{\circ} \mathrm{C}$ w Legionowie i od $1,5^{\circ} \mathrm{C}$ do $-3,6^{\circ} \mathrm{C}$ w Łebie. Dni z jego ekstremalnie niskimi wartościami najczęściej występowały w sezonie letnim z maksimum w lipcu - odpowiednio 61 dni we Wrocławiu, 56 w Legionowie i 46 w Łebie (ryc. 2). W półroczu chłodnym zaznaczało się częstsze występowanie omawianych dni w Łebie. Prawdopodobnie jest to związane ze sprzyjającymi warunkami dla rozwoju konwekcji uniesionej - napływ cieplejszego i wilgotnego powietrza znad morza ponad wychłodzoną przyziemną warstwę powietrza. Wskaźnik ten charakteryzował się wyraźną zmiennością z roku na rok. Najwięcej dni charakterystycznych wystąpiło w 2007 r. w Łebie (25) i w Legionowie (26), a w 2014 r. we Wrocławiu (24). Najmniej z kolei w 2005 r. w Legionowie (12), w 2008 r. w Łebie (10) oraz w 2013 r. we Wrocławiu (33).

Obliczona dla przyjętych ekstremów średnia indeksu SWI osiągała najniższe wartości w czerwcu we Wrocławiu $\left(-0,6^{\circ} \mathrm{C}\right)$. W przypadku Legionowa zbliżonymi wartościami cechował się okres od maja do sierpnia (około $-0,9^{\circ} \mathrm{C}$ ), a w Łebie okres od maja do sierpnia i październik (od $-1,1^{\circ} \mathrm{C}$ do $-1,3^{\circ} \mathrm{C}$ ) (ryc. 3). Najniższe wartości mediany wystąpiły we Wrocławiu w czerwcu $\left(-0,3^{\circ} \mathrm{C}\right)$, w Legionowie w sierpniu $\left(0,8^{\circ} \mathrm{C}\right)$ i w Łebie w maju $\left(0,26^{\circ} \mathrm{C}\right)$. Absolutne minima wartości wskaźnika SWI wyniosły $-4,9^{\circ} \mathrm{C}$ ( 29 lipca 2005 r. $)$ we Wrocławiu, $-4,5^{\circ} \mathrm{C}$ (6 lipca 2012 r. ) w Legionowie i $-3,6^{\circ} \mathrm{C}$ (18 lipca 2009 r.) w Łebie.

\section{Total Totals Index}

Ekstremalne wartości wskaźnika TTI mieściły się w przedziale od $52,8^{\circ} \mathrm{C}$ do $61,9^{\circ} \mathrm{C}$ we Wrocławiu, od $53,7^{\circ} \mathrm{C}$ do $62,5^{\circ} \mathrm{C}$ w Legionowie i od $54,0^{\circ} \mathrm{C}$ do $63,3^{\circ} \mathrm{C}$ w Lebie. Liczba dni z takimi wartościami cechowała się wyraźnym uprzywilejowaniem okresu zimowego i wiosennego. Najczęściej występowały one w kwietniu (27) i grudniu (29) we Wrocławiu, w marcu (33) i grudniu (27) w Legionowie oraz w styczniu (33) i grudniu (35) w Łebie (ryc. 2). Odmienny przebieg roczny wskaźnika TTI w stosunku do pozostałych indeksów wynika ze sposobu jego obliczania uwzględniającego wartości temperatury powietrza na poziomach izobarycznych 850 i $500 \mathrm{hPa}$ i temperatury punktu rosy na poziomie izobarycznym $850 \mathrm{hPa}$. Wskaźnik ten osiąga najwyższe wartości przy występowaniu dużego gradientu obu charakterystyk w pionowym przekroju atmosfery, co w strefie klimatu umiarkowanego jest związane najczęściej z pojawianiem się głębokiej doliny geopotencjału i towarzyszącemu jej silnemu prądowi strumieniowemu. Warunki takie sprzyjają adwekcji chłodnego i suchego 

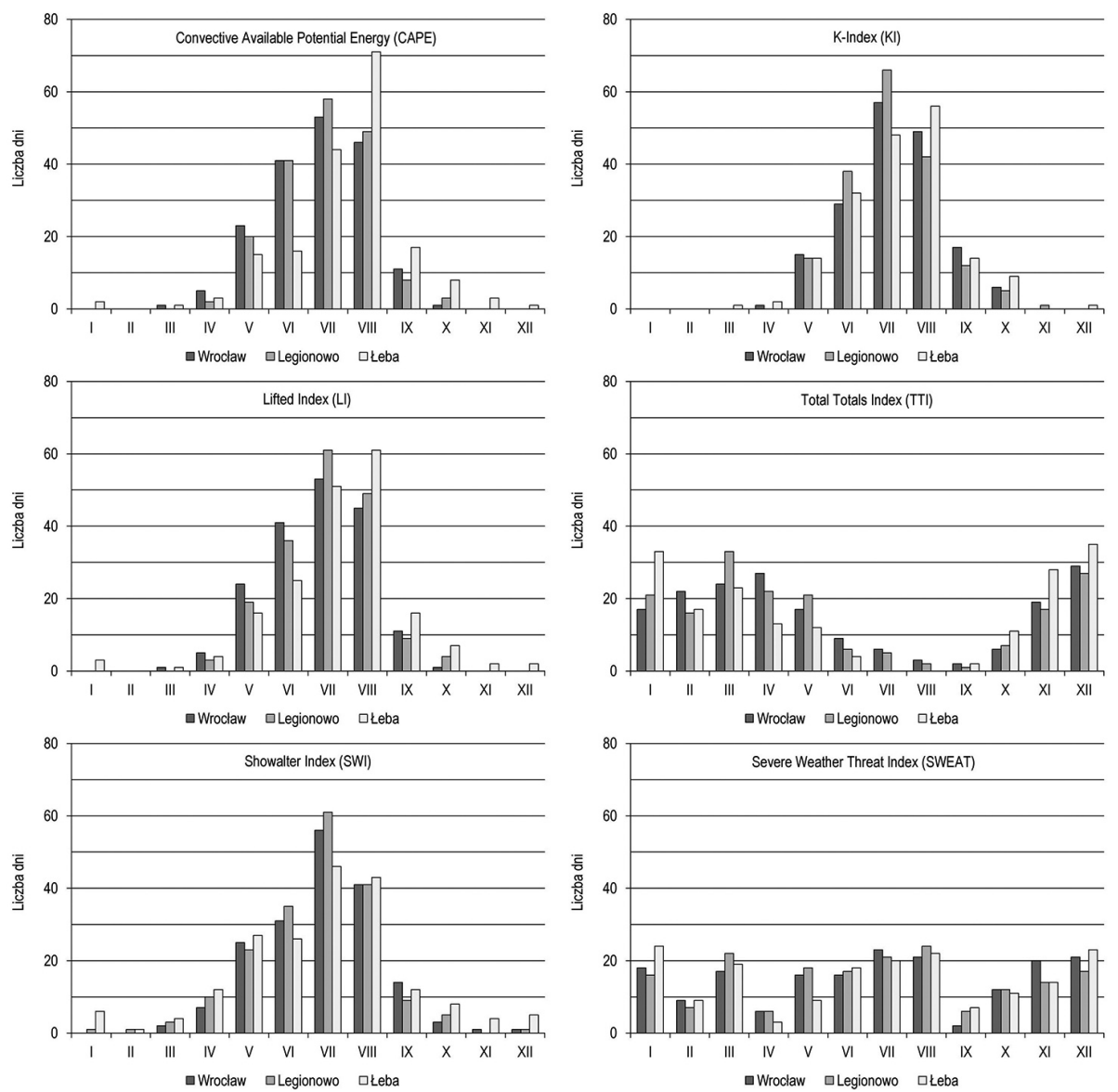

Ryc. 2. Roczny przebieg liczby dni z ekstremalnymi wartościami wybranych wskaźników chwiejności atmosfery w latach 2005-2014 w Legionowie, Łebie i Wrocławiu

Fig. 2. Annual course of days with extreme values of the selected instability indices in the period 2005-2014 in Legionowo, Łeba and Wrocław

powietrza na poziomie $500 \mathrm{hPa}$. Znaczne różnice widoczne są także w rozkładzie z roku na rok. W badanym okresie najwięcej omawianych dni charakterystycznych wystąpiło w 2005 r. w Legionowie (25), w 2007 r. w Łebie (31), a w 2008 r. we Wrocławiu (27). Najmniej zaś w 2014 r. w Legionowie (9), Łebie (12) i we Wrocławiu (11).

Średnia z ekstremalnych wartości wskaźnika TTI na wszystkich trzech stacjach aerologicznych cechowała się wyrównanym przebiegiem rocznym i wahała się w gra- 

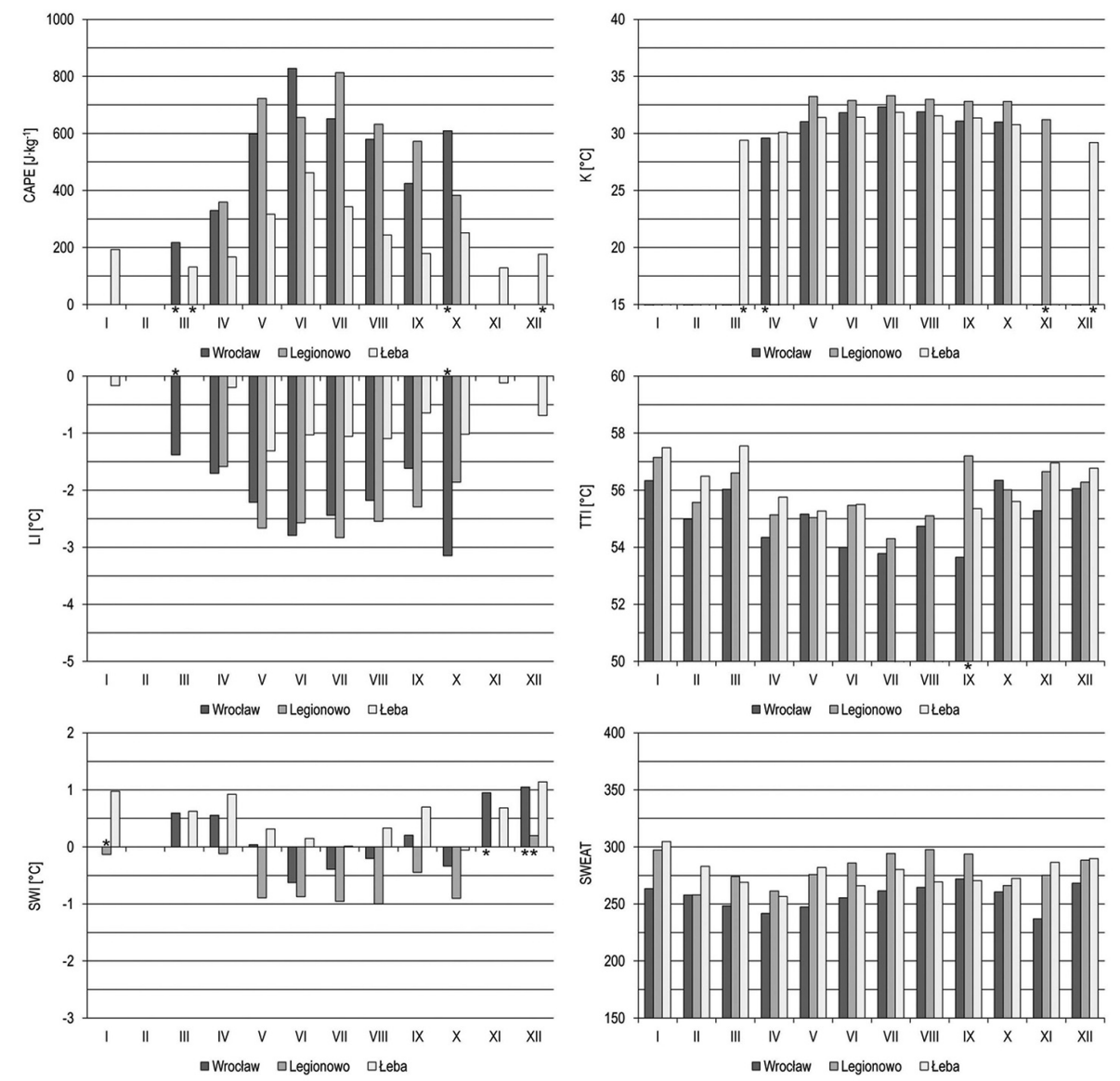

Ryc. 3. Przebieg roczny średniej z ekstremalnych wartości wybranych wskaźników chwiejności atmosfery w latach 2005-2014 w Legionowie, Łebie i Wrocławiu ( ${ }^{*}$ - jeden przypadek w miesiącu) Fig. 3. Annual course of mean calculated from the extreme values of the selected instability indices in the period 2005-2014 in Legionowo, Leba and Wrocław ( ${ }^{*}-$ one case a month)

nicach od $54,0^{\circ} \mathrm{C}$ do $57,0^{\circ} \mathrm{C}$ (ryc. 3 ). Wyjątek stanowiła stacja w Łebie, gdzie w lipcu i sierpniu nie zostały osiągnięte wartości ekstremalne. Najwyższe wartości mediany wynosiły $56,4^{\circ} \mathrm{C}$ w październiku we Wrocławiu, $56,4^{\circ} \mathrm{C}$ w styczniu w Legionowie i $57,6^{\circ} \mathrm{C}$ w marcu w Łebie. Absolutne maksima wartości indeksu TTI wyniosły $61,9^{\circ} \mathrm{C}$ ( 24 stycznia 2005 r.) we Wrocławiu, $62,5^{\circ} \mathrm{C}$ ( 6 grudnia 2013 r. ) w Legionowie i $63,3^{\circ} \mathrm{C}$ (22 listopada 2008 r.) w Łebie. 


\section{Severe Weather Threat Index}

Ekstremalne wartości (ekstremum górne) wskaźnika SWEAT mieściły się w przedziale od 217,0 do 424,1 we Wrocławiu, od 233,5 do 423,5 w Legionowie oraz od 237,4 do 410,3 w Łebie. Liczba dni z omawianymi wartościami progowymi wykazywała najbardziej wyrównany przebieg roczny spośród wszystkich analizowanych wskaźników (ryc. 2). Najmniejszą liczbą dni charakterystycznych cechowały się przejściowe pory roku, w szczególności kwiecień i wrzesień. Najczęściej natomiast występowały one w miesiącach charakteryzujących się dużą chwiejnością termodynamiczną, tj. w czerwcu, lipcu i sierpniu, oraz dużymi uskokami wiatru - w grudniu, styczniu i marcu. Wskaźnik ten charakteryzował się także wyraźną zmiennością z roku na rok. Najwięcej omawianych dni wystąpiło w 2007 r. w Łebie (27), w Legionowie (24) i we Wrocławiu (28). Najmniej zaś w 2006 r. w Legionowie (13), w 2010 r. w Łebie (9) oraz w 2013 r. we Wrocławiu (12).

Średnia z ekstremalnych wartości wskaźnika SWEAT cechowała się wyrównanym przebiegiem rocznym i wahała się od 237,0 (listopad) do 272,0 (wrzesień) we Wrocławiu; od 258,0 (luty) do 298,6 ( sierpień) w Legionowie; i od 256,4 (kwiecień) do 304,7 (styczeń) w Łebie (ryc. 3). Absolutne maksima wartości indeksu SWEAT wyniosły 424,1 (6 grudnia 2013 r.) we Wrocławiu, 423,5 (6 grudnia 2013 r.) w Legionowie i 410,3 (20 grudnia 2014 r.) w Łebie.

\section{Mechanizmy ograniczające rozwój konwekcji w warunkach ekstremalnych wartości wskaźników chwiejności - analiza przypadków}

\section{Legionowo, 11 września 2012}

Obszar Europy Środkowej znajdował się pod wpływem odsuwającego się na wschód układu wyżowego z centrum na pograniczu Ukrainy i Rosji. Blokował on swobodne przemieszczanie się głębokiego ośrodka niskiego ciśnienia w kierunku wschodnim (ryc. 4). Związana z tym niżem przedfrontowa strefa konwergencji wolno się przesuwała, docierając nad obszar Mazowsza dopiero 12 września około godziny 3.00 UTC. Oznacza to, że 11 września środkowa Polska pozostawała poza zasięgiem oddziaływania wielkoskalowych mechanizmów wspomagających rozwój konwekcji, tj. frontów atmosferycznych lub stref konwergencji. Jednocześnie czynnikiem potencjalnie sprzyjającym rozwojowi komórek burzowych była wysoka temperatura powietrza - temperatura maksymalna wynosiła od $28,0^{\circ} \mathrm{C}$ do $31,0^{\circ} \mathrm{C}$. Rozwój zjawisk konwekcyjnych został jednak zahamowany m.in. ze względu na bardzo niską 


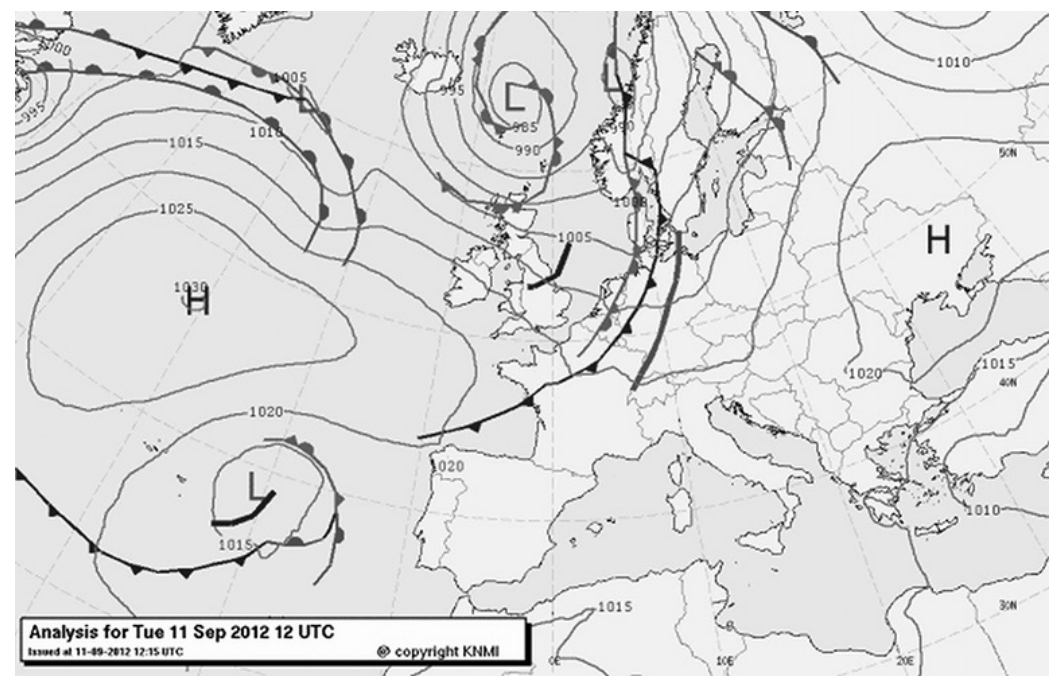

Ryc. 4. Mapa synoptyczna dolna, 11 września 2012 r., godz. 12.00 UTC (http://www.knmi. $\mathrm{nl} /$ klimatologie/daggegevens/weerkaarten/, 30.06.2015)

Fig. 4. MSL pressure map, 11 September 2012, 12.00 UTC (http://www.knmi.nl/klimatologie/ daggegevens/weerkaarten/, 30.06.2015)

wilgotność względną powietrza, która w godzinach od 12.00 do 15.00 UTC nie przekraczała $40 \%$.

Wszystkie rozpatrywane indeksy chwiejności atmosfery charakteryzowały się stosunkowo wysokimi wartościami - jedynie wskaźnik TTI nie osiągnął wartości ekstremalnych mimo że wskazywał on na możliwość wystąpienia rozproszonych i silnych burz. Pozostałe wskaźniki informowały o występowaniu znacznej ilości energii dostępnej dla konwekcji CAPE oraz dużym prawdopodobieństwie wystąpienia rozbudowanych układów konwekcyjnych K Index. Również wskaźniki LI i SWI przyjmowały wartości znacznie poniżej zera, co wskazywało na występowanie dużej chwiejności w dolnej troposferze. Ponadto znacznymi wartościami charakteryzowały się wskaźniki SBCAPE oraz DCAPE, który sugerował występowanie korzystnych warunków do rozwoju silnych prądów zstępujących (tab. 2).

Kolejnym czynnikiem ograniczającym rozwój silnych zjawisk konwekcyjnych było występowanie między poziomami 900 i 750 hPa warstwy hamującej, która była związana z utrzymującą się na wysokości od 1500 do $1800 \mathrm{~m}$ warstwą izotermiczną oraz napływem bardziej suchych mas powietrza w dolnej troposferze (ryc. 5). Konsekwencją tego była znaczna ilość dostępnej energii hamującej - wskaźnik CIN sięgał $-70 \mathrm{~J} \cdot \mathrm{kg}^{-1}$. Dodatkowo wysoko położony - na wysokości ok. $2000 \mathrm{~m}$ - poziom 
Tab. 2. Wartości wskaźników chwiejności atmosfery

Table 2. Values of the in stability indices

\begin{tabular}{|c|c|c|c|c|}
\hline & \multirow{2}{*}{$\begin{array}{l}\text { Wskaźnik } \\
\text { Index }\end{array}$} & \multicolumn{3}{|c|}{$\begin{array}{l}\text { Miejscowość, data i godzina sondażu } \\
\text { Place, date and time of the upper air sounding }\end{array}$} \\
\hline & & $\begin{array}{c}\text { Legionowo } \\
11.09 .2012 \\
12.00 \text { UTC } \\
\end{array}$ & $\begin{array}{c}\text { Łeba } \\
25.08 .2011 \\
\text { 12.00 UTC } \\
\end{array}$ & $\begin{array}{c}\text { Wrocław } \\
\text { 17.08.2006 } \\
\text { 12.00 UTC }\end{array}$ \\
\hline \multirow{9}{*}{ 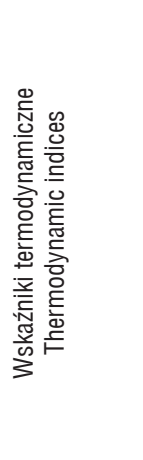 } & CAPE $\left[J \cdot \mathrm{kg}^{-1}\right]$ & 610 & 160 & 299 \\
\hline & $\mathrm{SBCAPE}^{\star}\left[\mathrm{J} \cdot \mathrm{kg}^{-1}\right]$ & 540 & 270 & 320 \\
\hline & $\mathrm{CIN}^{*}\left[\mathrm{~J} \cdot \mathrm{kg}^{-1}\right]$ & -69 & -111 & -22 \\
\hline & $\mathrm{SBCIN}^{*}\left[\mathrm{~J} \cdot \mathrm{kg}^{-1}\right]$ & -50 & -90 & -10 \\
\hline & $\mathrm{LI}\left[{ }^{\circ} \mathrm{C}\right]$ & $-3,5$ & $-0,1$ & $-0,6$ \\
\hline & $\mathrm{K}$ Index $\left[{ }^{\circ} \mathrm{C}\right]$ & 32,9 & 29,5 & 30,9 \\
\hline & SWI $\left[{ }^{\circ} \mathrm{C}\right]$ & $-1,3$ & 2,9 & 0,9 \\
\hline & $\operatorname{TTI}\left[{ }^{\circ} \mathrm{C}\right]$ & 53,4 & 44,2 & 47,2 \\
\hline & $\mathrm{DCAPE}^{\star}\left[\mathrm{J} \cdot \mathrm{kg}^{-1}\right]$ & 900 & 390 & 590 \\
\hline \multirow{2}{*}{ 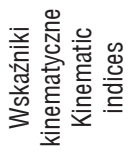 } & $\begin{array}{l}0-3 \mathrm{~km} \text { shear*} \\
{\left[\mathrm{m} \cdot \mathrm{s}^{-1}\right]}\end{array}$ & 8,6 & 7,9 & 6,2 \\
\hline & $\begin{array}{l}0-6 \mathrm{~km} \text { shear* } \\
{\left[\mathrm{m} \cdot \mathrm{s}^{-1}\right]}\end{array}$ & 6,7 & 13,6 & 8,8 \\
\hline \multirow{2}{*}{ 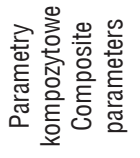 } & SWEAT Index & 280,4 & 138,7 & 152,1 \\
\hline & $\mathrm{DCP}$ * & 0,2 & 0,1 & 0,1 \\
\hline
\end{tabular}

* SBCAPE (Surface-Based CAPE) - energia dostępna dla konwekcji cząstki unoszonej z powierzchni ziemi; CIN (Convective Inhibition) - energia hamująca konwekcję; SBCIN (Surface-Based CIN) - energia hamująca konwekcję dla cząstki unoszonej z powierzchni Ziemi; DCAPE (downdraft CAPE) - energia potencjalna prądów zstępujących; 0-3 km shear - uskok wiatru z dolnych $3 \mathrm{~km}$ troposfery; 0-6 km shear - uskok wiatru z dolnych $6 \mathrm{~km}$ troposfery; DCP (derecho composite parameter) - parametr określający prawdopodobieństwo wystąpienia zjawiska derecho wartości pogrubione - wartości wskaźników przekraczających 5 bądź 95 percentyl 


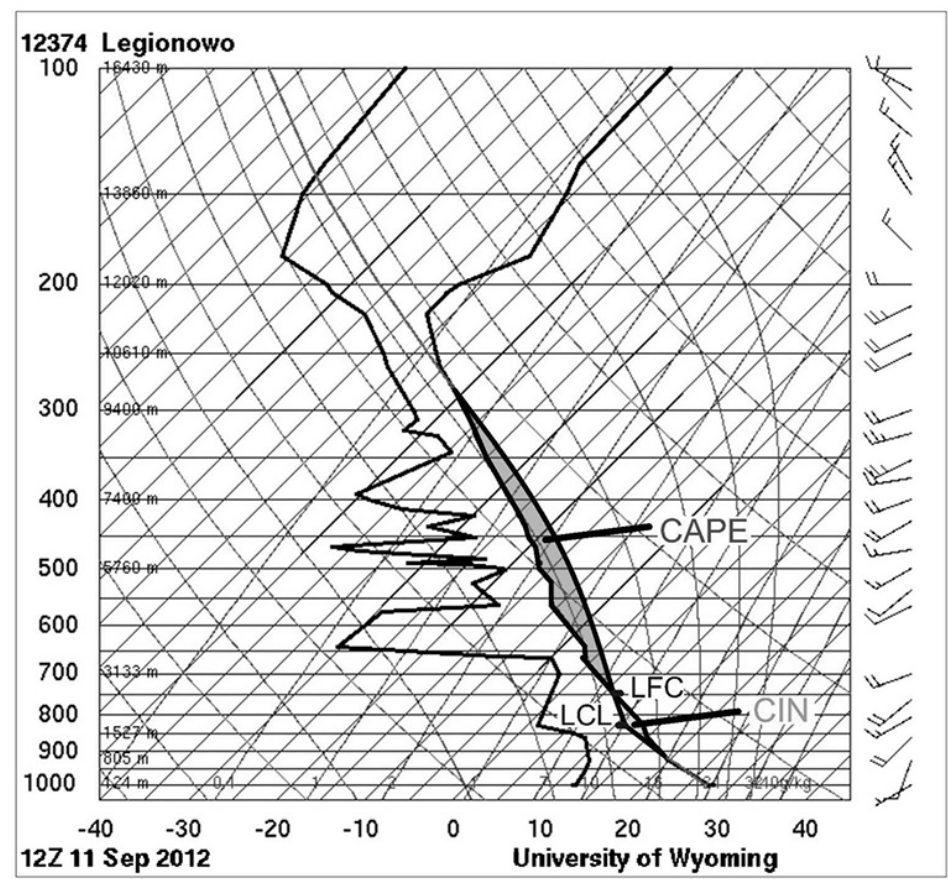

Ryc. 5. Sondaż aerologiczny, 11 września 2012 r., Legionowo, 12.00 UTC (http://weather. uwyo.edu/upperair/sounding.html, 15.02.2015)

Fig. 5. Upper air sounding plot, 11 September 2012 r., Legionowo, 12.00 UTC (http://weather. uwyo.edu/upperair/sounding.html, 15.02.2015)

kondensacji (Lifting Condensation Level - LCL) i jego stosunkowo duża odległość od poziomu swobodnej konwekcji (Level of Free Convection - LFC) skutecznie uniemożliwiły rozbudowę chmur kłębiastych i komórek burzowych. Niskie wartości wskaźników kinematycznych nie zapewniały dogodnych warunków do dyssypacji warstwy hamującej.

\section{Łeba, 25 sierpnia 2011}

Europa Środkowa znajdowała się w strefie granicznej między nasuwającym się z zachodu płytkim układem niżowym a układem wyżowym z centrum nad Rosją. Około godziny 12.00 UTC obszar Polski pozostawał pod wpływem słabogradientowego obszaru podwyższonego ciśnienia, co można uznać za jeden z elementów ograniczających rozwój głębokiej konwekcji. Nad Półwyspem Jutlandzkim 
przemieszczał się wówczas pofalowany front atmosferyczny, który jednak szybko uległ rozproszeniu i zaniknięciu (ryc. 6). Dodatkowym czynnikiem mogącym sprzyjać silnym zjawiskom konwekcyjnym była wysoka temperatura powietrza (temperatura maksymalna przekraczała $25,0^{\circ} \mathrm{C}$ ) i znaczna wilgotność względna (średnia wartość dobowa osiągała 85\%-95\%).

Spośród wszystkich wybranych wskaźników chwiejności atmosfery trzy osiągnęły zakładane wartości ekstremalne. Odpowiednio wskaźnik LI prognozował możliwość pojawienia się słabych burz, K-Index 41\%-60\% prawdopodobieństwo wystąpienia rozproszonych burz, a wskaźnik CAPE wskazywał możliwą niewielką intensywność konwekcji. Znacznie wyższe wartości osiągał obliczany z powierzchni Ziemi wskaźnik SBCAPE (tab. 2). Ponadto czynnikiem sprzyjającym rozwojowi ruchów pionowych była

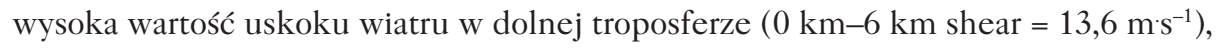
która mogła prowadzić do rozwoju wielokomórkowych układów konwekcyjnych nawet przy niewielkich wartościach wskaźników termodynamicznych. Rozwojowi konwekcji sprzyjał potencjalnie także bardzo nisko położony poziom kondensacji (LCL) występujący na wysokości ok. $500 \mathrm{~m}$ nad powierzchnią. Za główną przyczynę niewystąpienia silnych zjawisk konwekcyjnych na analizowanym obszarze należy

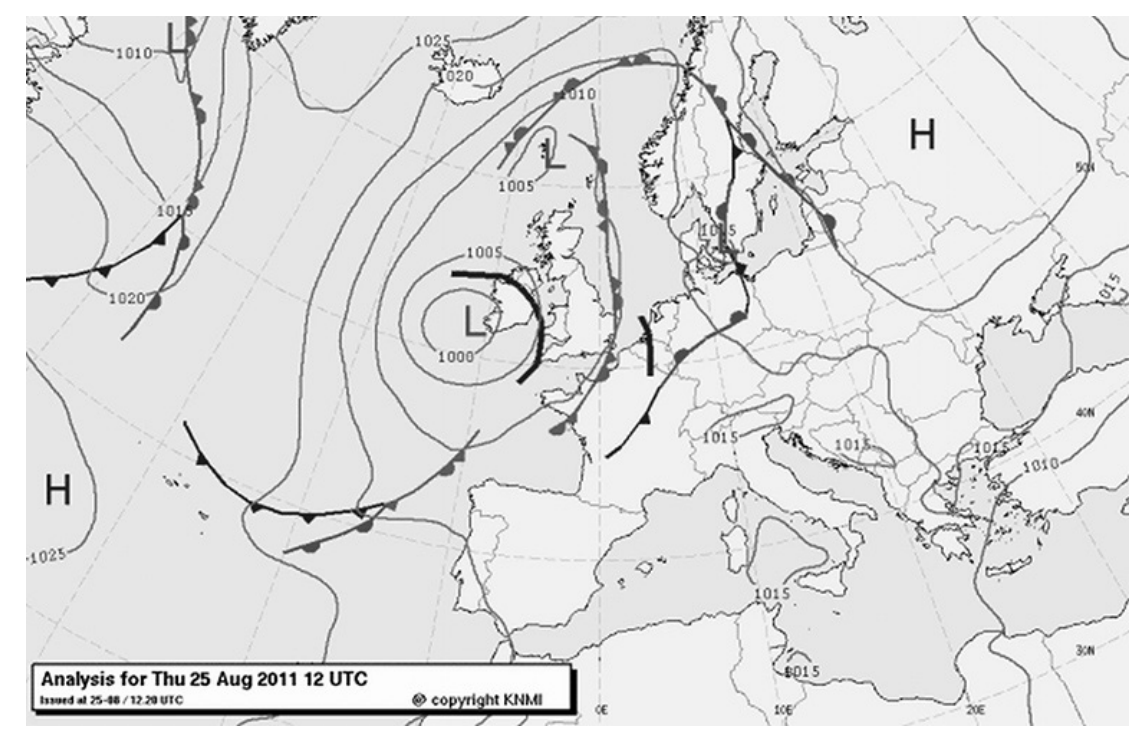

Ryc. 6. Mapa synoptyczna dolna, 25 sierpnia 2011 r., godz. 12.00 UTC (http://www.knmi.nl/ klimatologie/daggegevens/weerkaarten/, 30.06.2015)

Fig. 6. MSL pressure map, 25 August 2011, 12.00 UTC (http://www.knmi.nl/klimatologie/ daggegevens/weerkaarten/, 30.06.2015) 


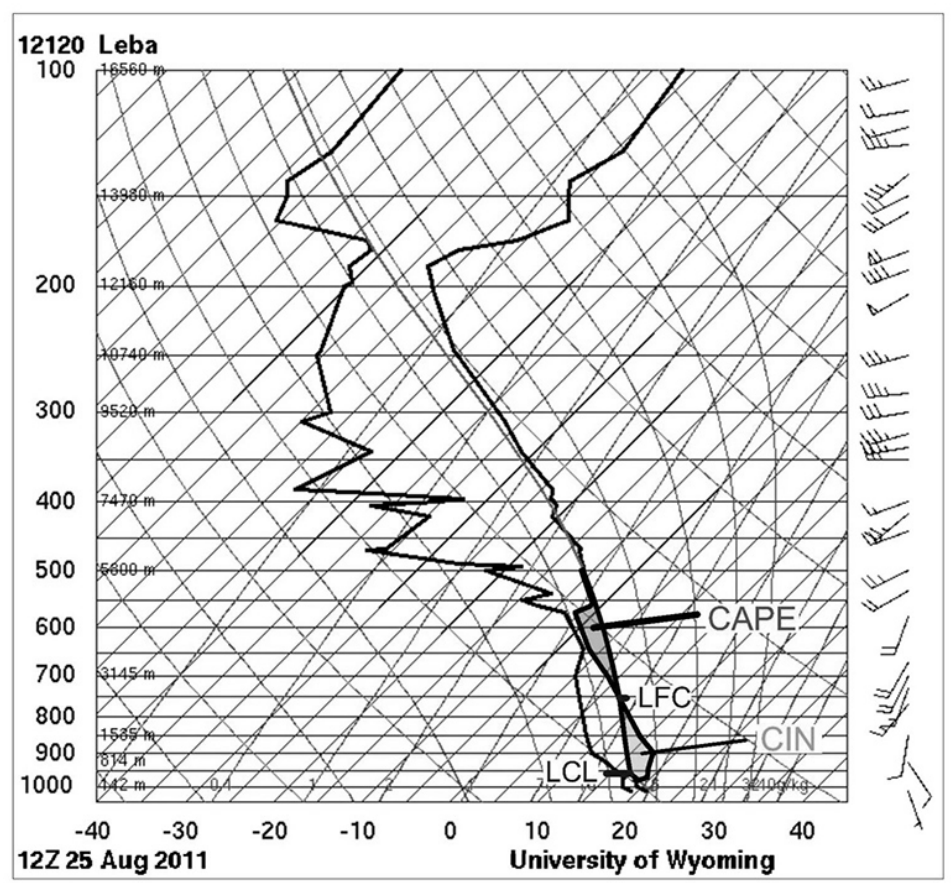

Ryc. 7. Sondaż aerologiczny, 25 sierpnia 2011 r., Łeba, 12.00 UTC (http://weather.uwyo.edu/ upperair/sounding.html, 15.02.2015)

Fig. 7. Upper air sounding plot, 25 August 2011, Łeba, 12.00 UTC (http://weather.uwyo.edu/ upperair/sounding.html, 15.02.2015)

uznać zaleganie warstwy hamującej między poziomami 975 hPa i $750 \mathrm{hPa}$ (ryc. 7). Wskaźnik CIN osiągnął wówczas wartość-111 J·kg-1 . Dodatkowo warstwy inwersyjne o znacznej miąższości występowały zarówno w dolnej (między poziomami $980 \mathrm{hPa}$ a $970 \mathrm{hPa}$ ), jak i w środkowej troposferze - między poziomami $750 \mathrm{hPa}$ a $560 \mathrm{hPa}$. Czynniki te nie tylko uniemożliwiały rozwój chmur kłębiastych w przypowierzchniowych warstwach atmosfery, ale również utrudniłyby dalszy rozwój konwekcji przy ewentualnej dyssypacji pierwszej warstwy inwersyjnej.

\section{Wrocław, 17 sierpnia 2006}

Europa Środkowa znajdowała się na skraju układu wysokiego ciśnienia z centrum nad pograniczem Rosji, Białorusi i Ukrainy. Równocześnie w rejonie kanału La Manche zalegał układ niskiego ciśnienia, co skutkowało napływem 


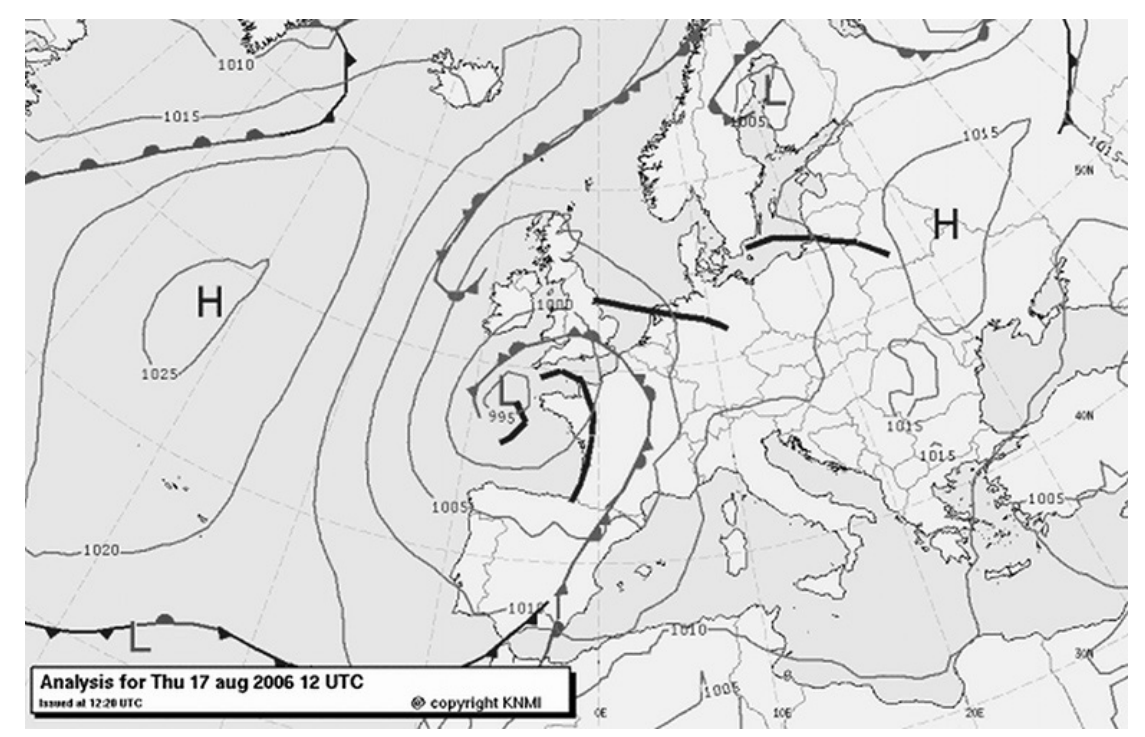

Ryc. 8. Mapa synoptyczna dolna, 17 sierpnia 2006 r., godz. 12.00 UTC (http://www.knmi.nl/ klimatologie/daggegevens/weerkaarten/, 30.06.2015)

Fig. 8. MSL pressure map, 17 August 2006, 12.00 UTC (http://www.knmi.nl/klimatologie/ daggegevens/weerkaarten/, 30.06.2015)

nad Polskę ciepłych i suchych mas powietrza z południa kontynentu (ryc. 8). $\mathrm{W}$ południowo-zachodniej Polsce temperatura maksymalna wynosiła od $28,0^{\circ} \mathrm{C}$ do $31,0^{\circ} \mathrm{C}$, a średnia dobowa wilgotność względna osiągała około 50\%-60\%. O godzinie 12.00 UTC na części stacji synoptycznych spadła ona nawet poniżej 40\%, co nie sprzyjało rozwojowi konwekcji.

Trzy z analizowanych wskaźników chwiejności atmosfery osiągnęły zakładane wartości ekstremalne. Wskaźnik K-Index sugerował 41-60-procentowe prawdopodobieństwo wystąpienia rozproszonych burz, wskaźnik SWI prawdopodobne słabe burze, a wskaźnik CAPE możliwą niewielką intensywność konwekcji. Podwyższone wartości wykazywał także DCAPE informujący o energii prądów zstępujących (tab. 2).

Głównym czynnikiem ograniczającym rozwój konwekcji było występowanie dwóch warstw hamujących położonych między poziomami $850 \mathrm{hPa}$ i $750 \mathrm{hPa}$ oraz między poziomami $590 \mathrm{hPa}$ i $580 \mathrm{hPa}$. Dość niskie wartości wskaźnika CIN w połączeniu z wysoko położonym poziomem kondensacji (LCL) i brakiem wielkoskalowych czynników wspomagających konwekcję skutecznie zahamowały rozwój ruchów pionowych powietrza (ryc. 9). 


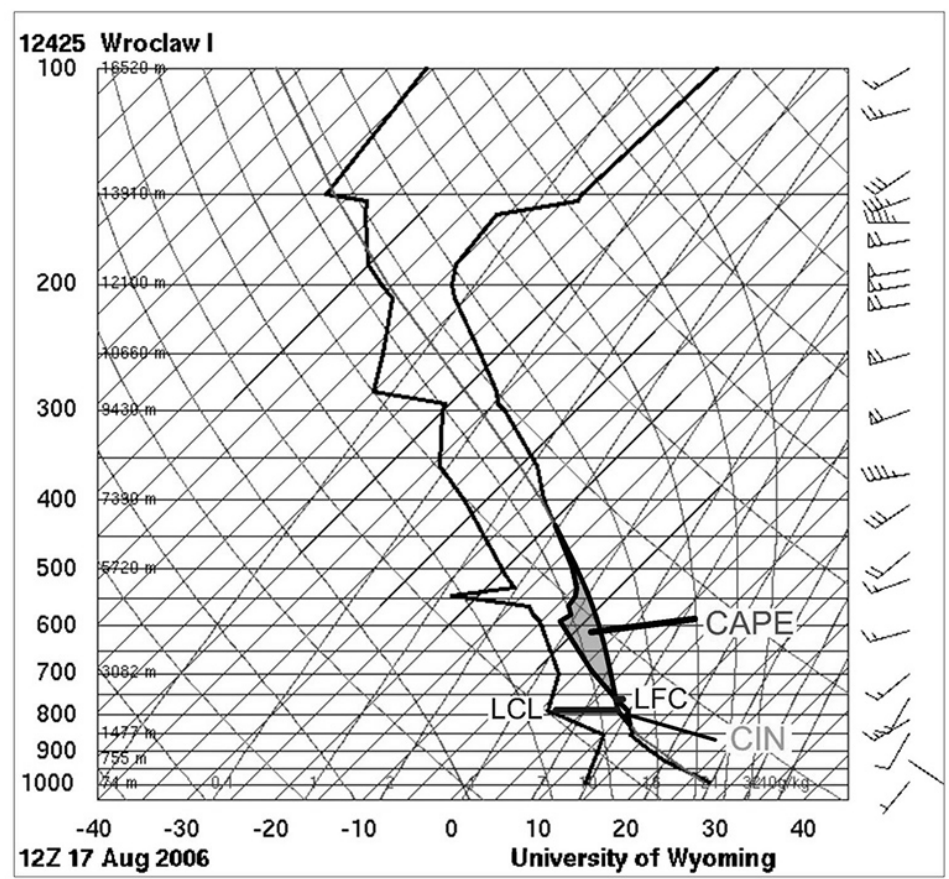

Ryc. 9. Sondaż aerologiczny, 17 sierpnia 2006 r., Wrocław, 12.00 UTC (http://weather.uwyo. edu/upperair/sounding.html, 15.02.2015)

Fig. 9. Upper air sounding plot, 17 August 2006, Wrocław, 12:00 UTG (http://weather.uwyo. edu/upperair/sounding.html, 15.02.2015)

\section{Dyskusja i wnioski}

Przeprowadzone badania dowiodły istnienia silnej czasowej i przestrzennej zmienności ekstremalnych wartości wskaźników chwiejności atmosfery. Analogicznie do badań zmienności omawianych indeksów w Europie prowadzonych przez Romero i in. (2007) oraz Siedleckiego (2009) zaobserwowano wyraźny cykl roczny występowania liczby dni z wartościami ekstremalnymi, a także dużą zmienność w rozkładzie średnich z ekstremalnych wartości analizowanych indeksów. Wyjątek stanowił cechujący się niewielką zmiennością roczną kompozytowy wskaźnik SWEAT, którego wysokie wartości mogły wynikać zarówno ze znacznej chwiejności termodynamicznej (szczególnie w sezonie ciepłym), jak i z dużych wartości uskoków wiatru (szczególnie w sezonie chłodnym). Termodynamiczne wskaźniki CAPE, K-Index, LI i SWI potwierdziły występowanie najbardziej sprzyjających warunków do rozwoju 
konwekcji w okresie od maja do września. Wartość wskaźnika TTI, który jest obliczany z uwzględnieniem temperatury powietrza na poziomach izobarycznych $850 \mathrm{hPa}$ i $500 \mathrm{hPa}$ oraz temperatury punktu rosy na poziomie izobarycznym $850 \mathrm{hPa}$, sugerowała natomiast duże możliwości rozwoju zjawisk konwekcyjnych również w sezonie chłodnym. Jest to najczęściej konsekwencją występowania w strefie klimatu umiarkowanego głębokiej doliny geopotencjału i towarzyszącemu jej silnemu prądowi strumieniowemu w środkowej i górnej troposferze.

Analiza danych pomiarowych ze stacji aerologicznych pozwoliła również na zidentyfikowanie wyraźnego zróżnicowania przestrzennego. Było ono związane głównie z charakterem powierzchni czynnej w otoczeniu stacji. Dowiedziony przez Siedleckiego i Rzepę (2008) związek między odległością od Oceanu Atlantyckiego i stopniem kontynentalizmu a wartościami wskaźników chwiejności uwidocznił się również w przypadku analizowanych w tym artykule stacji. Oddziaływanie Morza Bałtyckiego w Łebie wpływało na wyraźne przesunięcie miesięcznego maksimum częstości występowania ekstremalnych wartości wielu indeksów oraz ich pojawianie się w sezonie jesienno-zimowym.

Analiza wybranych przypadków dowiodła, że ograniczenie pionowych ruchów powietrza w warunkach ekstremalnych wartości indeksów chwiejności było związane głównie z występowaniem warstw hamujących - izotermii lub inwersji w swobodnej atmosferze. Dodatkowym czynnikiem utrudniającym rozwój konwekcji w tych dniach było położenie badanego obszaru poza zasięgiem oddziaływania wielkoskalowych mechanizmów wspomagających, tj. frontów atmosferycznych i stref zbieżności oraz relatywnie wysokie położenie poziomu swobodnej konwekcji.

\section{Literatura}

Blanchard D.O., 1998, Assessing the vertical distribution of Convective Available Potential Energy, Weather and Forecasting, 13, 870-877.

Brooks H.E., 2009, Proximity soundings for severe convection for Europe and the United States from reanalysis data, Atmospheric Research, 93, 546-553.

Brooks H.E., Anderson A.R., Riemann K., Ebbers I., Flachs H., 2007, Climatological aspects of convective parameters from the NCAR/NCEP reanalysis, Atmospheric Research, 83, 294-305.

Brooks H.E., Lee J.W., Craven J.P., 2003, The spatial distribution of severe thunderstorm and tornado environments from global reanalysis data, Atmospheric Research, 67-68, 73-94.

Čabajová Z., 2011, Vetrová kalamita v roku 2004 vo Vysokých Tatrách - pričiny, priebeh, dôsledky a obnova postihnutého územia, [w:] A. Pribullová (red.), Meteorológia a klimatológia vo vyučovaní II, Vzduch v pohybe, Vydal Geofyzikálny ústav SAV, Bratislava, 59-63.

Chaboureau J.-P., Guichard F., Redelsperger J.-L., Lafore J.-P., 2004, The role of stability and moisture in the diurnal cycle of convection over land, Quarterly Journal of the Royal Meteorological Society, 130 (604), 3105-3117. 
DeRubertis D., 2006, Recent trends in four common stability indices derived from U.S. radiosonde observations, Journal of Climate, 19, 309-323.

Doswell III C.A., Carbin G.W., Brooks H.E., 2012, The tornadoes of spring 2011 in the USA: An historical perspective, Weather, 67 (4), 68-94.

Galway J.G., 1956, The lifted index as a predictor of latent instability, Bulletin of the American Meteorological Society, 37, 528-529.

George J.J., 1960, Weather forecasting for aeronautics, Academic Press, London.

Gubenko I.M., Rubinshtein K.G., 2015, Analysis of the results of thunderstorm forecasting based on atmospheric instability indices using the WRF-ARW numerical model data, Russian Meteorology and Hydrology, 40 (1), 16-24.

Hand W.H., Cappelluti G., 2011, A global hail climatology using the UK Met Office convection diagnosis procedure (CDP) and model analyses, Meteorological Applications, 18, 446-458.

Miller R.C., 1972, Notes on analysis and severe-storm forecasting procedures of the Air Force Global Weather Central, Scott Air Force Base, IL, 190.

Moncrieff M.W., Miller M.J., 1976, The dynamics and simulation of tropical cumulonimbus and squall-lines, Quarterly Journal of the Royal Meteorological Society, 102, 373-394.

Palencia C., Giaiotti D., Stel F., Castro A., Fraile R., 2010, Maximum hailstone size: Relationship with meteorological variables, Atmospheric Research, 96, 256-265.

Rauhala J., Schultz D.M., 2009, Severe thunderstorm and tornado warnings in Europe, Atmospheric Research, 93, 369-380.

Riemann-Campe K., Fraedrich K., Lunkeit F., 2009, Global climatology of Convective Available Potential Energy (CAPE) and Convective Inhibition (CIN) in ERA-40 reanalysis, Atmospheric Research, 93, 534-545.

Romero R., Gaya M., Doswell II C.A., 2007, European climatology of severe convective storm environmental parameters: A test for significant tornado events, Atmospheric Research, 83, 389-404.

Sanchez J.L., Marcos J.L., Dessens J., Lopez L., Bustos C., Garcia-Ortega E., 2009, Assessing sounding-derived parameters as storm predictors in different latitudes, Atmospheric Research, 93, 446-456.

Showalter A.K., 1953, A stability index for thunderstorm forecasting, Bulletin of the American Meteorological Society, 34, 250-252.

Siedlecki M., 2009, Selected instability indices in Europe, Theoretical and Applied Climatology, 96, 85-94.

Siedlecki M., Rzepa M., 2008, Charakterystyka catkowitej energii chwiejności atmosfery nad Europq w latach 1991-2003, Przegląd Geofizyczny, 53 (1), 43-54.

Wong S., Dessler A.E., 2005, Suppression of deep convection over the tropical North Atlantic by the Saharian Air Layer, Geophysical Research Letters, 32 (L09808), 1-4.

Venkat Ratnam M., Durga Santhi Y., Rajeevan M., Vijaya Bhaskara Rao S., 2013, Diurnal variability of stability indices observed using radiosonde observations over a tropical station: Comparison with microwave radiometer measurements, Atmospheric Research, 124, 21-33. 


\section{Strony internetowe}

http://weather.uwyo.edu/ (15.02.2015).

http://www.estofex.org (15.06.2015).

http://www.eswd.eu/ (15.04.2015).

http://www.ipcc.ch (15.02.2015).

http://www.knmi.nl/ (30.06.2015).

http://www.lightningmaps.org (15.06.2015).

http://www.ogimet.com/ (15.04.2015).

http://www.wetterzentrale.de (15.06.2015).

http://www.wetter3.de (15.06.2015).

Daniel Celiński-Mystaw

Uniwersytet Jagielloński w Krakowie

Instytut Geografii i Gospodarki Præestræennej

ul. Gronostajowa 7, 30-387 Kraków

daniel.celinski-myslaw@doctoral.uj.edu.pl

Angelika Palar:

Uniwersytet Jagielloński w Krakowie

Instytut Geografii i Gospodarki Præestræennej

ul. Gronostajowa 7, 30-387 Kraków

angelika.palar:@doctoral.uj.edu.pl 